\title{
How might we identify and measure learning progression in history?
}

\author{
Dr Louise Zarmati \\ University of Tasmania \\ https://doi.org/10.37517/978-1-74286-638-3_19
}

\begin{abstract}
Dr Louise Zarmati is a Lecturer in Humanities and Social Sciences Education at the University of Tasmania in Australia. She has had a varied career as a teacher, archaeologist and museum educator. Louise's research focuses on history pedagogy in primary and secondary classrooms and museums, as well as the integration of archaeology and Indigenous knowledges into the school curriculum.

In 2009-10 Louise worked for ACARA as a writer of the Australian Curriculum: History (K-10) and Senior Ancient History Courses. In 2018 she was invited by the OECD to conduct research on international examples of learning progression in History.
\end{abstract}

\section{Introduction}

As recently as the 1990s, history was taught in many schools and universities in Western countries as 'content', or what is now called 'historical knowledge'. History was presented as a succession of dates and events that students were expected to memorise and regurgitate in formal examinations. This narrow focus on content made history tedious for many young people and it was not unusual to hear them complain that they did not like the subject because they could not remember a string of boring dates and facts.

Of course, factual recall is an important part of understanding history as well as other subjects, but if factual recall is considered the main purpose of learning history, then memorisation becomes the key skill learned, not a broader understanding of the nature of history itself.

Fortunately, the study of history has changed dramatically since the 1990 s, from a simple focus on the memorisation of people, dates and events to the cognitive understanding of historical concepts and the use of historical skills.

\section{What is 'history'?}

History is a dynamic subject that is constantly reshaped in response to changes in research and interpretation over time. Postmodernists remind us that history is a construct that is subject to the variables of time and place. Historical knowledge is geographically and temporally specific and can differ within nations, states and local regions, depending on which knowledge (such as people, dates, and events) is considered at the time to be historically significant. 


\section{The processes of 'doing' history}

In the 1970s and 1980s, British researchers undertook a study that examined how students aged 7 to 14 years understood history (Lee, 2005; Lee \& Ashby, 2000; Lee et al., 1996). They separated the learning of history into two distinct areas:

\section{Knowing about history - Substantive knowledge and understanding}

This encompasses knowing the details of history, such as names, dates, people, events and places. It also includes the understanding of broad concepts such as colonisation, imperialism, peasant, revolution, ideology, kingship, society, liberty, and feudalism.

\section{Doing history - Procedural knowledge}

This encompasses the concepts and skills you need to be able to do history. These include understanding concepts such as evidence, continuity and change, and cause and effect in order to make sense of the past. It also requires the ability to describe or explain concepts, and to analyse and evaluate the usefulness and reliability of sources.

Substantive and procedural knowledge build on each other and should function together. It is impossible for students to understand or make use of procedural knowledge if they have no knowledge of the substance of the past.

\section{Historical inquiry}

Students use historical knowledge and skills to investigate the past through the process of historical inquiry. It is the heuristic used by educators to teach history. History is problematised as a dilemma, conflict, mystery or contradiction that is analysed, dissected and interpreted.

During the process of historical inquiry, students can do the same work as academic and professional historians but without the same sophistication and complexity. They can ask historical questions, identify contradictions and conflicts, and develop interpretations supported by historical evidence.

Fundamental to historical inquiry is the interrogation and critical evaluation of primary sources, which can be written, visual or archaeological. Students analyse written primary sources such as eyewitness accounts, diaries and newspaper reports, and images such as photographs, postcards, and paintings. They can also examine artefacts such as pottery, weapons, statues, coins, and jewellery, and old or ancient objects of everyday life.

Students also learn to critically evaluate secondary sources, which are sources created after the historical event by someone who did not participate in or experience the event first-hand. Scholarly books, textbooks, research articles and documentaries are examples of secondary sources.

\section{What does it mean to 'think historically'?}

Students think historically when they use primary sources as evidence about what happened in the past. They demonstrate their ability to understand different interpretations of the past and, ultimately, use historical evidence to develop their own interpretations.

In order to understand progression in history, students should use a combination of substantive and procedural knowledge in the process of historical thinking. It is a student's ability to demonstrate that they can think historically that is measured as evidence of learning progression in history. 


\section{What is learning progression in history?}

Learning progression is a continuum that measures advances in learning by tracking development from early learning to more sophisticated levels of mastery. Mathematics relies on an understanding of empirical knowledge and concepts in a hierarchical sequence; students need to understand (or master) one mathematical concept before they can proceed to the next.

In comparison, progress of understanding in history is not necessarily hierarchical because it is based on mastery of concepts and skills rather than historical knowledge, which is geographically and temporally variable.

With history, it is not necessary to progress sequentially from one concept in order to comprehend another; learning is measured by mastery of levels of complexity within each skill or understanding and mastery can be concurrent and interrelated.

The essential characteristic of progression in history is that students can demonstrate an increase in their cognitive ability to think analytically and critically.

\section{Learning progression in the Australian Curriculum: History}

Substantive and procedural knowledge are differentiated in the Australian Curriculum as:

- knowledge and understanding (substantive)

- inquiry and skills (procedural)

The job of the teacher is to design learning activities that develop procedural concepts and skills that are inherently tied to specific historical knowledge and contexts that develop a holistic awareness of students' understanding. Teachers can measure students' progress over a designated period (e.g. a semester, a year, or two years) by designing assessments that demonstrate mastery of historical skills and concepts rather than by simply testing students' ability to memorise historical knowledge.

Well-designed learning programs and activities allow progression to take place according to the individual student's abilities rather than at prescribed age or stage levels. Concepts are deepened and strengthened by continuous revisiting, and students work towards mastery of each skill or concept. A hierarchy of concepts and skills, linked to knowledge and understanding, can be derived from the Australian Curriculum to measure progression in history.

\section{Indicators of learning progression in the Australian Curriculum: History}

Indicators of learning progression, or improvement, are evident in the Australian Curriculum's yearly Achievement Standards. Action verbs describe students' cognitive development and articulate a hierarchical taxonomy of learning. For example, in Year 4, students recognise the significance of events in bringing about change, and in Year 5 they progress to being able to describe the significance of people and events/developments in bringing about change (See Table 1).

When measured over a designated period of time and reported as a continuum of development, (e.g. over two semesters, or over two years) it is possible to track students' progression in understanding the concepts of significance and continuity and change, as well as their ability to move from recognising to describing. Likewise, in Year 7, students 'describe the effects of change on societies, individual and groups', and in Year 8 they progress to 'explain[ing] the causes and effects of events and development' (See Table 2). 
We should be mindful that progression levels can vary greatly within a class because individual students have different learning abilities and can therefore progress at different rates. A student's performance may not necessarily neatly align with year groups or chronological age.

For example, a Year 4 student who may be particularly interested and 'gifted' at learning history may be operating at Year 6 level in terms of their ability to analyse and evaluate historical sources and construct an argument. Alternatively, a student who has English as a second language (ESL) or foreign language (EFL) may understand the historical concepts but struggle with presenting their findings in written and/or spoken English. The progress of individual students should be accounted for by using differentiated identifiers that consider such variables.

Table 1 Learning progression from Year 4 to Year 5 (adapted from ACARA 2021)

\begin{tabular}{|c|c|}
\hline $\begin{array}{l}\text { By the end of Year } 4 \text { (age 10) a student will } \\
\text { be able to: }\end{array}$ & $\begin{array}{l}\text { By the end of Year } 5 \text { (age 11) a student will } \\
\text { be able to: }\end{array}$ \\
\hline $\begin{array}{l}\text { Recognise the significance of events in bringing } \\
\text { about change }\end{array}$ & $\begin{array}{l}\text { Describe the significance of people and events/ } \\
\text { developments in bringing about change }\end{array}$ \\
\hline Explain how and why life changed in the past & $\begin{array}{l}\text { Identify the causes and effects of change on } \\
\text { particular communities }\end{array}$ \\
\hline $\begin{array}{l}\text { Identify aspects of the past that have remained } \\
\text { the same }\end{array}$ & $\begin{array}{l}\text { Describe aspects of the past that have remained } \\
\text { the same }\end{array}$ \\
\hline $\begin{array}{l}\text { Describe the experiences of an individual or group } \\
\text { in the past }\end{array}$ & $\begin{array}{l}\text { Describe the experiences of different people in the } \\
\text { past }\end{array}$ \\
\hline $\begin{array}{l}\text { Sequence information about events and the lives of } \\
\text { individuals in chronological order with reference to } \\
\text { key dates }\end{array}$ & $\begin{array}{l}\text { Sequence information about events and the lives of } \\
\text { individuals in chronological order using timelines }\end{array}$ \\
\hline Develop questions about the past & Develop questions for a historical inquiry \\
\hline \multicolumn{2}{|l|}{$\begin{array}{l}\text { Locate, collect and sort information from different } \\
\text { sources to answer questions }\end{array}$} \\
\hline $\begin{array}{l}\text { Identify and select a range of sources and locate, } \\
\text { compare and use information to answer inquiry } \\
\text { questions }\end{array}$ & $\begin{array}{l}\text { Identify a range of sources and locate, collect and } \\
\text { organise information related to an inquiry }\end{array}$ \\
\hline Analyse sources to detect points of view & $\begin{array}{l}\text { Analyse sources to determine their origin and } \\
\text { purpose and to identify different viewpoints }\end{array}$ \\
\hline $\begin{array}{l}\text { Develop and present texts, including narrative } \\
\text { recounts using historical terms }\end{array}$ & $\begin{array}{l}\text { Develop, organise and present texts, particularly } \\
\text { narrative recounts and descriptions, using historical } \\
\text { terms and concepts }\end{array}$ \\
\hline
\end{tabular}

Note: red text, historical thinking concept; purple text, historical skill 
Table 2 Learning progression from Year 7 to Year 8 (adapted from ACARA 2021)

\begin{tabular}{|c|c|}
\hline $\begin{array}{l}\text { By the end of Year } 7 \text { (age 13) a student will } \\
\text { be able to: }\end{array}$ & $\begin{array}{l}\text { By the end of Year } 8 \text { (age 14) a student will } \\
\text { be able to: }\end{array}$ \\
\hline $\begin{array}{l}\text { Suggest reasons for change and continuity over } \\
\text { time }\end{array}$ & $\begin{array}{l}\text { Recognise and explain patterns of change and } \\
\text { continuity over time }\end{array}$ \\
\hline $\begin{array}{l}\text { Describe the effects of change on societies, } \\
\text { individuals and groups }\end{array}$ & $\begin{array}{l}\text { Explain the causes and effects of events and } \\
\text { developments }\end{array}$ \\
\hline $\begin{array}{l}\text { Describe events and developments from the } \\
\text { perspective of different people who lived at the time }\end{array}$ & $\begin{array}{l}\text { Identify the motives and actions of people at the } \\
\text { time }\end{array}$ \\
\hline $\begin{array}{l}\text { Explain the role of groups and the significance of } \\
\text { particular individuals in society }\end{array}$ & $\begin{array}{l}\text { Explain the significance of individuals and groups } \\
\text { and how they were influenced by the beliefs and } \\
\text { values of their society }\end{array}$ \\
\hline $\begin{array}{l}\text { Identify past evens and developments that have } \\
\text { been interpreted in different ways }\end{array}$ & Describe different interpretations of the past \\
\hline $\begin{array}{l}\text { Sequence events and developments within a } \\
\text { chronological framework, using dating contentions } \\
\text { to represent and measure time }\end{array}$ & $\begin{array}{l}\text { Sequence events and developments within a } \\
\text { chronological framework with reference to periods } \\
\text { of time }\end{array}$ \\
\hline $\begin{array}{l}\text { Develop questions to frame a historical inquiry } \\
\text { when researching }\end{array}$ & $\begin{array}{l}\text { Develop questions to frame a historical inquiry } \\
\text { when researching }\end{array}$ \\
\hline $\begin{array}{l}\text { Identify and select a range of sources and locate, } \\
\text { compare and use information to answer inquiry } \\
\text { questions }\end{array}$ & $\begin{array}{l}\text { Analyse, select and organise information from } \\
\text { primary and secondary sources and use it as } \\
\text { evidence to answer inquiry questions }\end{array}$ \\
\hline Examine sources to explain points of view & $\begin{array}{l}\text { Identify and explain different points of view in } \\
\text { sources }\end{array}$ \\
\hline $\begin{array}{l}\text { Identify their origin and purpose when interpreting } \\
\text { sources }\end{array}$ & $\begin{array}{l}\text { Identify their origin and purpose and distinguish } \\
\text { between fact and opinion when interpreting } \\
\text { sources }\end{array}$ \\
\hline $\begin{array}{l}\text { Use historical terms and concepts, incorporate } \\
\text { relevant sources, and acknowledge their sources of } \\
\text { information in developing texts and organising and } \\
\text { presenting their findings }\end{array}$ & $\begin{array}{l}\text { Use historical terms and concepts, and evidence } \\
\text { identified in sources, and acknowledge their sources } \\
\text { of information when organising and presenting } \\
\text { their findings }\end{array}$ \\
\hline
\end{tabular}

Note: red text, historical thinking concept; purple text, historical skill

\section{Measuring learning progression in history}

Although curriculum documents provide teachers with guidelines and descriptors of learning progression at different stages in a continuum of learning, measuring a student's progression in history is not necessarily an easy task. Measurement of progression is usually achieved by using some form of assessment and then reporting the results. Unfortunately, there is no single formula or model for designing assessments to identify learning progression in history. The challenge is for educators to design appropriate assessment instruments that effectively reflect, measure and report on students' learning.

If the overall aim of learning is for students to improve, then assessment should be an instrument designed to identify, diagnose, and articulate improvement in relation to what the student could do before, rather than only reporting what the student can do at the time of assessment.

Researchers advise that diagnosis is best achieved through formative assessment that allows teachers to not only assess students' learning, but most importantly, assess the effectiveness of their teaching (see Carr \& Counsell, 2014; William, 2011). The teacher should be able to identify students' strengths and weaknesses so that learners can improve and progress (Phillips, 2002). Assessment should not conflate attainment (or achievement) and progress; it should provide students and teachers with meaningful information on how they both can improve in the future. 
Meaningful assessment descriptors should articulate the knowledge, conceptual understandings and skills that are typical for a learner to achieve at each level. These can be identified in assessments in the following ways:

1. Benchmarks or standards that are measurable criteria against which learning can be evaluated. These are often developed at a macro level by state or national assessment authorities. Benchmarks might be set for the level at which concepts or skills must be mastered in each grade. They might also be used to determine where a particular student, class, or school ranks in comparison to others. Meyer and Land (2006) call this point of mastery 'threshold concepts', which are determined to be central to a subject, and when understood by students, allow them to 'cross the threshold' of their understanding of that subject. Similarly, British history educator Alex Ford (2016) calls this a 'signpost'.

2. Learning outcomes, objectives, goals that are clear descriptions of what a learner is expected to be able to do, know about and/or value at the completion of learning. They describe the substance of learning and how its attainment will be demonstrated. These are often developed at the micro level, in schools, grades or classes for lessons or sequences of lessons.

Threshold concepts or signposts are also valid measures of progression at the micro levels of class, grade and school.

The challenge is for teachers to develop progression models and assessment instruments that clearly define levels of proficiency that reflect an individual's level of achievement and the complexity of their learning.

\section{References}

Australian Curriculum, Assessment and Reporting Authority (ACARA) (2021). Retrieved 1 August, 2021 from http://australiancurriculum.edu.au/f-10-curriculum/humanities-and-social-sciences/

Carr, E., \& Counsell, C. (2014). Using timelines in assessment. Teaching History, 157, 54-62.

Ford, A. (2016). Progress and progression in history. http://www.andallthat.co.uk/ uploads/2/3/8/9/2389220/apf_-_progression_pack.pdf

Lee, P. J. (2005). Historical literacy: Theory and research. International Journal of Historical Learning, Teaching and Research, 5(1). https://www.researchgate.net/publication/242158846_Historical_ Literacy_Theory_and_Research

Lee, P. J., \& Ashby, R. (2000). Progression in historical understanding among students ages 7-14. In P. N. Stearns, P. Seixas, \& S. Wineburg (Eds.), Knowing, teaching, and learning history, pp. 192-222. New York University Press.

Lee, P. J., Ashby, R., \& Dickinson, A. K. (1996). Progression in children's ideas about history. In M. Hughes (Ed.), Progression in learning, pp. 51-81. Multilingual Matters.

Meyer, J. H. F., \& Land, R. (2006). Overcoming barriers to student understanding: Threshold concepts and troublesome knowledge. Routledge.

Phillips, R. (2002). Historical significance: The forgotten key element. Teaching History, 106, 14-19.

William, D. (2011). Embedded formative assessment. Solution Tree Press. 